\title{
Meghan Elizabeth Kallman, The Death of Idealism: Development and Anti-politics in the Peace Corps, Columbia University Press, New York, 2020, pp320. ISBN: 9,780,231,189,699. \$28.00/£22.00
}

\author{
James Mawanda ${ }^{1}$ (D)
}

Accepted: 19 January 2021 / Published online: 11 February 2021

(C) The Author(s) 2021

The Death of Idealism: Development and Anti-politics in the Peace Corps is a product of several years of Meghan Elizabeth Kallman's assistant professorship at the School of Global Inclusion and Social Development at the University of Massachusetts Boston. Although this book appears to be intended for social sciences, other spheres such as political science, international relations, development studies, and development economics will find it incredibly relevant. The book is organized into five chapters.

Chapter one sets forth the main components of Meghan's arguments. Kallman introduces the concept of voluntarism, the basis of the Peace Corps work. However, from the onset, she contrasts volunteerism as used by the Peace Corps. She critiques that "their organizational involvement and their pay make them more like wage earners; hence the salience is more similar to that of employees than that of volunteers as traditionally defined" (p. 27). However, she acknowledges that volunteerism is about helping people to help themselves fight poverty sustainably.

Chapter two introduces the reader to the theory of the historical dynamics that led to the Peace Corps' establishment. Notably Kallman maintains that the need to assist developing countries in the 1960s amidst the US and Russia's geopolitical fights was a driving factor embedded in Washington's foreign policy design. Her concerns are

Book review editor: Marc Jegers.

James Mawanda

mawandajames@gmail.com

Euclid University (Alumnus), Kampala, Uganda shared by G. Gyimah, who recognizes "the United States Peace Corps as a facet of the U SA." 1

Additionally, she equates Peace Corps to the Marshall Plan of the 1940s that the USA used towards the European allies when she mentions that "the Marshall Plan was a US initiative with the discrete goal of stabilizing Europe" (p. 65).

In Chapter three, the concept of procedural professionalism is introduced, as embedded in the Peace Corps' work. Volunteers must perform their duties according to their philosophy, thinking, and belief, thus thwarting their inherent abilities and talents. Certainly, this kind of behavior and approach reflect the Peace Corps as a direct and indirect US foreign policy arm. Moreover, from a sophisticated system design, the teaching of the English Language, cultural and democratic values as promoted by the USA, the approach pacifies the communities in which Peace Corps operates. In essence, Washington's foreign policy interests, particularly in the developing world, are partly promoted by the Peace Corps. The author's submissions are shared by HL Bourke, who concurs that the "often-overlooked socio-cultural, relational, and spatial aspects of cultural strategies aim at generating soft power."

In Chapter four, the reader is taken to the theory of legitimacy, where the Peace Corps strives to conform to the laws and rules in the developing world to be admissible. Throughout the book, Kallman reiterates that volunteers are trained to ensure Peace Corps gains legitimacy globally

\footnotetext{
${ }^{1}$ Godwin Gyimah, "Into the World We Go, the Peace Corps Program as a Facet of America-Ghana Relations," 2020.

${ }^{2}$ Hannah Louise Bourke, "Taiwan in Their Hands: Cultural Soft Power and Translocal Identity Making in the New York Taiwan Academy," 2019.
} 
to ease its work. As a result, whether or not the Peace Corps is welcome in the developing world is not cited in this book. Thus, she concludes that "the organizational and programmatic emphasis is put on the individual as the agent of change" (p. 118). M. Svoboda consents to Meghan's views and adds that these young men and women "reinforce white saviorism and American imperialism." 3

Chapter five introduces the reader to the concept of internationalists or cosmopolitans as the volunteers tend to refer to themselves at the end of the day. Kallman indicates that volunteers start their tenure with the Peace Corps with different ideologies, which gradually disappear as the years go by. Generally, this comes from the volunteers' international experience and exposure plus the training that they go through. Whereas this training may affect the volunteers' ideological tendencies, the book does not come out clearly on the interviewees' academic background, which can be a critical factor in the responses, depending on the dreams after school. Secondly, the interviewees' areas of allocation can favorably affect the reactions depending on the experiences.

Moreover, a volunteer who spent only two years does not have the same level of experience as one who spent ten years with the organization. For instance, volunteers posted in Europe might not go through the same experience as one posted in South Sudan, Cambodia, or even Yemen. The European Union has a strong influence in Eastern Europe, which might ease working conditions for the volunteers, which is not the case in Africa or Asia.

Thirdly, whereas the book focuses much on the feelings, thoughts, and emotions about volunteers' work, the reactions and responses may not be exhaustive given that these are workers of the Federal Government, affected by the confidentiality clauses contained in the Federal Government Laws. In essence, volunteers would not open up entirely due to "information that is properly classified in the interest of national defense or foreign policy." 4

Despite the limitations mentioned above, all in all, Kallman's book is of great relevance, for it unmasks the dynamics of volunteerism in the Peace Corps, which revelations can apply to other international development organizations. Nonetheless, what is happening to these volunteers during and after their tenure should never be ignored. All said, the book is a must-read for all those who have a keen interest in international development and fighting poverty since the two are interdisciplinary in the contemporary world.

Open Access This article is licensed under a Creative Commons Attribution 4.0 International License, which permits use, sharing, adaptation, distribution and reproduction in any medium or format, as long as you give appropriate credit to the original author(s) and the source, provide a link to the Creative Commons licence, and indicate if changes were made. The images or other third party material in this article are included in the article's Creative Commons licence, unless indicated otherwise in a credit line to the material. If material is not included in the article's Creative Commons licence and your intended use is not permitted by statutory regulation or exceeds the permitted use, you will need to obtain permission directly from the copyright holder. To view a copy of this licence, visit http://creativecommons. org/licenses/by/4.0/.

Publisher's Note Springer Nature remains neutral with regard to jurisdictional claims in published maps and institutional affiliations.
3 Madison Svoboda, "White Saviorism and American Imperialism: An Analysis of the Peace Corps," 2020.

\footnotetext{
4 “Privacy Program," accessed December 26, 2020, https://www. peacecorps.gov/about/privacy/.
} 